\title{
Syllabus Design for Computer Extracurricular Based on Internet of Things
}

\author{
Dias Agata \\ $\frac{\text { diasagatahendra@gmail.com }}{* * *}$ \\ Adnan Rachmad Anom Besari, \\ *** \\ Iwan Kurnianto Wibowo \\ *** \\ Berliana Cahyaniati Purnomo Putri \\ Politeknik Elektronika Negeri \\ Surabaya, Indonesia
}

\begin{abstract}
This research presents the process of designing syllabus for computer extracurricular that will be used in a junior high school in Indonesia, namely Al Uswah Junior High School, Surabaya. This study will determine the basic competencies that students need to master to learn Internet of Things (IoT) and the ideal syllabus design so that students are able to master all basic competencies related to IoT. In designing the new syllabus, first of all, the STEM curriculum is obtained from schools, then needs analysis is done. Internet of Things was seen as the most suitable approach and then chosen as the main material for the extracurricular. Then, the syllabus is designed based on the regulation of Indonesian Ministry of Education and Culture and Revised Bloom Taxonomy. After that, six basic competencies were formulated and adapted into six learning materials. Then the indicators are chosen in accordance with the competency standards of junior high school students. Cognitive domain verbs from the knowledge dimension (factual, conceptual, procedural and metacognitive) are used in each indicator of competence achievement. Various learning activities in the syllabus are comprehensively designed so that students can perform practical work in accordance with the learning materials. Learning facilities in each section cover practicum teaching modules, power points, videos, practicum tool modules, and LCD projectors. The assessments for students include written tests, practicum and making products. Each assessment is adjusted to the basic competency and learning materials that have been formulated. The results shows that that all indicators mentioned in the syllabus are in accordance with the competency standards of junior high school students.
\end{abstract}

Keywords: Curriculum, Syllabus, Junior High School, Internet of Things, Revised Bloom Taxonomy.

\section{Introduction}

The booming population around 258 representation where the number of million people in Indonesia, greatly affects the level of Indonesian welfare. The ASEAN Economic Community (AEC) will further improve the economic competitiveness of the people in Indonesia. In 2020-2030, Indonesia is predicted to enter the peak of demographic bonus year. Bonus demography is a productive age is greater than the unproductive age. Statistical data in 2016 shows that $50 \%$ of Indonesia population is of productive age, equivalent to 166.06 million people (Annisa, 2017). The target population that has the best quality and opportunity in facing the demographic bonus of 2030 is the 
Z generation (generation born in 1995-2010) who are currently aged between 7-22 years (Adam, 2017). This shows that most of the $Z$ generation is still in childhood and threatened to face the demographic bonus later.

The $\mathrm{Z}$ generation is a generation who is versatile, individual, global, open-minded, entrepreneurship focused, faster dive into the world of work and more technology-friendly. According to Hellen Katherina from Nielsen Indonesia, the $\mathrm{Z}$ generation is the future generation. However, the challenge that must be faced is that the generation is more inclined to have dependence on technologies such as gadgets, computers and the internet, which have an impact on excessive addiction that can affect mental decline, creativity and quality of learning. To deal with these problems, human resources need to be prepared through basic education from the early age. One of them is through the formal education curriculum. It also requires a form of application of digital technology activities so that children can be interested in applying technology to the realm of education. So that the output later can eliminate the bad habits of technology addiction without having to separate the technology from them completely. A design and implementation of Internet of Things-based computer learning media (IoT) is needed as a solution to these problems. The IoT-based STEM learning will later be applied to the extracurricular of schools in the computer field. Media connecting communication between students and IoT learning media is using Python language programming. Because Python has benefits to be easily learned by beginners. The main subject of this learning is children at the junior high school level because they have the ability to understand abstract science such as understanding programming languages.

\section{Research Questions}

The purpose of this study is to obtain a computer extracurricular syllabus design to improve the junior high school students' competency in the Science, Technology, Engineering and Mathematics (STEM), based on Internet of Things. In accordance with the purpose of the study, the following research questions were proposed: What are the basic competencies of junior high school's students need to learn Internet of Things? How is the ideal syllabus design so that students are able to master the basic competencies?

\section{Literature Review}

The competency standards of junior high school graduates in Indonesia as formulated in the Indonesia Minister of Education and Culture Regulation No. 20 of 2016 concerning the Competency Standards for Graduates of Primary and Secondary Education (Kemendikbud, 2016) are the basis of the preparation of Basic Competencies which will be derived in the syllabus design. Based on the knowledge dimension, the competency standards of junior high school graduates are expected to have simple factual, conceptual, procedural and metacognitive knowledge at a simple technical and specific level related to science, technology, art and culture and are able to relate the knowledge in the everyday context as an Indonesian citizen.

Syllabus is a learning plan for a particular subject or group that includes competency standards, basic competencies, subject matter or learning materials, learning activities, indicators of competence achievement, and assessment and learning 
resources (Depdiknas, 2005). The contents of the syllabus that meet the standards must be able to answer the following three questions: 1 . What are the competencies that students must master? 2. How to achieve it? 3. How to know the achievement?

The ideal syllabus design according to Republic of Indonesia Government Regulations (PP) Number 19 of 2005 concerning National Education Standards Article 20 is: syllabus must carry scientific value, relevant, systematic, consistent, adequate, actual and contextual, flexible and comprehensive (Depdiknas, 2005).

The Indonesian government's concern for the development of STEM teaching needs to be balanced with the readiness of the syllabus to implement the ideal teaching and learning process. One of the studies that has been done is in the form of research on the application of STEM that is adapted to IoT technology. The media used to implement IoT technology are Raspberry Pi and Python programming languages. Raspberry pi has lower price, easy and fast IoT implementation, and has an I / O port. While the Python programming language was chosen because it is one of the best programming languages (Rao, et al., 2018).

The Internet of Things (IoT) is an emerging global Internet-based information architecture facilitating the exchange of goods and services. The IoT has the purpose of providing IT-infrastructure facilitating the exchange of "things" in a secure and reliable manner, i.e. the function is to overcome the gap between objects in the world and their representation in information systems. The
IoT will serve to increase transparency and enhance the efficiency of global supply chain networks (Weber, 2010). IoT is the most relevant approach applied to computer extracurricular because in the current industrial revolution 4.0 era, the need for students' understanding of the development of IoT is very high, but the STEM curriculum at school has not been supportive. So that with the fulfillment of material about IoT in computer extracurricular activities, students are expected to be comprehensively understand the application of STEM especially IoT in everyday life.

The implementation of STEM in natural science learning in junior high schools is continued to refer to the 2013 curriculum. This study explained that STEM was in line with the principles of making the syllabus in the 2017 edition of the 2013 curriculum revision. At each level of education, there is a conceptual framework from STEM. Junior high school level is a level which the skills in the STEM field are explored through the activity of analyzing issues in solving problems. In addition, at this level, the subject of science and mathematics can be integrated in accordance with the concept of STEM. The integration process can be done through basic competencies so that in learning process, two basic competencies are achieved at once. To implement STEM in learning at junior high school, teachers can make a syllabus by integrating the basic competencies of the subject (Anggraini, et al., 2017).

\section{Method}

The Internet of Things-Based Computer Extracurricular syllabus is designed in order to carry out ideal teaching and learning activities in a directed manner and in accordance with the objectives of the extracurricular. The objective of computer extracurricular is to provide a forum for students to develop self-confidence, 
providing skills to students who have interests and talents in the field of Information and Communication Technology, directing students in the use of Information and Communication Technology tools.

"Knowledge", the achievement of cognition, is further divided into subcategories adapted to the development in the field of neuroscience and research which covers factual knowledge, conceptual knowledge, procedural knowledge, and metacognitive knowledge (Rukmini, 2009). This sub-category helps teachers and researchers to classify learning objectives, basic competencies or compile assessments more simply. These four sub-categories also appear to be a reference for the stipulation of the Ministry of Education and Culture Regulation No. 20 of 2016 concerning the Competency Standards for Graduates of Primary and Secondary Education (Kemendikbud, 2016). So the use of Revised Bloom Taxonomy is relevant for designing the syllabus in this study.

The first step in designing the syllabus is to apply the conformity of Competency Standards with the STEM curriculum that has been established by the school. After the adjustment, a number of Basic Competencies can be formulated from the Competency Standards. Basic Competency will be the basis for the design of the syllabus. Second, the basic competencies will be formulated based on the Revised Bloom Taxonomy (Rukmini, 2009). The basic competency will be the base in determining the learning materials related to IoT. Third, cognitive domain verbs from Revised Bloom Taxonomy will be used in establishing the indicators of competence achievement. Taxonomy's Revised Bloom Cognitive dimensions: Remember (C1), Understand
(C2), Apply (C3), Analyze (C4), Evaluate (C5 and Create (C6). Fourth, to embody the concept of technology in learning, a form of syllabus design that contains programming of the Internet of Things-based language as a learning media in the field of technology is made.

\section{The Need Analysis}

This syllabus design is prepared in accordance with the STEM curriculum that is applied in one of the private schools in Surabaya, namely Al Uswah Junior High School Surabaya. In this school, there is computer extracurricular that has been running for several years but still do not have an ideal syllabus to meet the needs of students which are adapted to the STEM curriculum.

To make the syllabus design, it is necessary to make plans and adjustments in accordance with the curriculum applied in $\mathrm{Al}$ Uswah Junior High School. To be able to create a syllabus that is appropriate, information about the learning curriculum that has been applied in formal schools is collected. Curriculum applied at the school today is the 2013 curriculum, which Computer lesson is not a compulsory course yet serves as the supporting facility for all courses at school. If computer lesson considered as a certain study hour, in curriculum 2013 it is located during hours of student's extracurricular activity.

\section{STEM}

STEM is an abreviation for Science, Technology, Engineering and Mathematics. STEM combines all parts of science, technology, engineering and mathematics in order to be applicable and realistic in understanding and solving a problem. If science and mathematics are integrated with technology and engineering, it can affect students' motivation in learning. They will 
feel that learning is memorable, interesting, fun, active, stimulating students' creative thinking skills and providing direct experience (Alfama, 2017).

In order for STEM education to be in accordance with education in Indonesia, the application of conformity is required. If the STEM components in the form of science and represents Science lesson, the technology will be manifested in mini PC or mini computer learning tools in the form of Raspberry Pi. If it is in the form of engineering, it will be manifested in the form of Internet of Things and if it is in the form of mathematics, it will be manifested in the Mathematics lesson. With the adjustment plan between STEM education and education in Indonesia, it is highly expected that STEM education can be best applied in Indonesia through Computer extracurricular based on Internet of Things.

\section{Internet of Things}

In this study the application of Computer extracurricular learning is based on the internet, because it is easy to implement and in accordance with everyday activities. In the syllabus, the application of STEM elements employs techniques and technology to utilize the use of Internet of Things.

Internet of Things (IoT) is an object that is connected wirelessly using smart sensors. In addition, IoT is considered as a part of the internet in the future and is consisting of billions of intelligent communications on objects around us. In Indonesia's education, IoT is often used as a learning medium in the classroom. The material related to IoT is web programming, mobile computing and embedded systems.

\section{Policy Studies}

The syllabus design for junior high school students will be adjusted to Republic of Indonesia Government Regulations (PP) Number 19 of 2005 concerning National Education Standards Article 20 is: syllabus must carry scientific value, relevant, systematic, consistent, adequate, actual and contextual, flexible and comprehensive (Depdiknas, 2005).

\section{Results and Analysis}

The curriculum in the destination school is in accordance with the graduates' competency standards which are having simple factual, conceptual, procedural and metacognitive knowledge at a simple technical and specific level related to science, technology. There are six basic competencies formulated from the Competency Standards: (1) Apply the concept of Internet of Things in daily life, (2) Employ Python language programming in daily life, (3) Apply the concept of measuring the quantities using standard units and sensors, (4) Present the results of experiments in investigating the characteristic of acid and base solutions, (5) Analyze the concept of temperature and its application in daily life, and (6) Present the experiments results of work.

Based on the six basic competencies, the syllabus are designed consisting six learning materials: The basic of the Internet of Things and Python, Python basic programming, Internet of Things on measurement and unit, Internet of Things on the application of acids and bases, Internet of Things at temperature and Internet of Things on work. The six basic competencies are described in six tables respectively.

The first learning material is The Basics of Internet of Things and Python. The purpose of this learning materials is students can comprehension the concept and the application from Internet of Things (IoT) in

Beyond Words Vol.6 No.2 (2018) 
daily life. Besides of that, the basic competencies that must be reached is that students are able to apply the concept of Internet of Things in daily life. This learning material is the base of the entire IoT learning.

The indicators of competence achievement are: First, they are able to name the definitions of Raspberry pi, Internet of Things and Python which represents C1. Second, they are able to elaborate the results of an investigation about using the Internet of
Things in daily life which represents C2, and third, they are able to classify the daily life problems that related with Internet of Things which represents C4. In the end of this section, students can remember, understand and analyze items related to the basics of IoT and Python. The reason of classifying is to determine the IoT application in daily life which related with the purpose and the basic competencies.

\section{Table 1}

\section{The Basics of the Internet of Things and Python}

\begin{tabular}{ll}
\hline Basic competencies & the concept of Internet of Things in daily life. \\
\hline Learning materials & The Basics of the Internet of Things and Python. \\
\hline Indicator & $\begin{array}{l}\text { Name the definitions of Raspberry pi, Internet of Things and } \\
\text { Python. } \\
\text { Elaborate the results of an investigation about using the Internet of } \\
\text { Things in daily life. } \\
\text { Classify the daily life problems that related with Internet of Things. }\end{array}$ \\
& $\begin{array}{l}\text { Observe the human activities daily life which related with Internet } \\
\text { of Things. } \\
\text { Make a solution model in daily life by using Internet of Things. }\end{array}$ \\
\hline Learning Activities & $\begin{array}{l}\text { Practicum learning module } \\
\text { Power point presentation }\end{array}$ \\
& $\begin{array}{l}\text { Video } \\
\text { Games } \\
\text { Practicum tool module } \\
\text { LCD Projector }\end{array}$ \\
\hline Assessment & written test \\
\hline Learning Resources & Raspberry Pi Cookbook, Simon Monk. \\
\hline
\end{tabular}

Teachers need to prepare several learning materials such as practicum teaching module, power point, video, game, practicum tool module and LCD projector. In first meeting, teacher will explain about the function of each learning facilities by video, power point and LCD projector. Lastly, teacher will show the education game that must be finished by students. The assessment is obtained from the writing test only.

The second learning material is about Python Basic Programming. This learning material is designed so that students can apply the basic of arithmetic, algebra and integer in Python programming language. The basic competencies must be reach is employ Python language programming in daily life.

The indicators of competence achievement are: students are keen to make a solution python program based on Arithmetic and Algebra which represents C6 and solve problems by using arithmetic, algebra and integer calculations which 
represents C4. In the end of this section, students can analyze and create items related to Python basic programming. The reason of this indicator is this section focused on the basic programming by arithmetic, algebra and integer calculations.

Table 2

Python Basic Programming

\begin{tabular}{|c|c|}
\hline Basic competencies & Employ Python language programming in daily life. \\
\hline Learning materials & Python basic programming \\
\hline Indicator & $\begin{array}{l}\text { - Make a solution python program based on Arithmetic and Algebra } \\
\text { - Solve problems by using arithmetic, algebra and integer calculations. }\end{array}$ \\
\hline Learning Activities & $\begin{array}{l}\text { - Experiment using python language programming in daily life. } \\
\text { - Presents the results of experiments with python and displayed in web or LCD } \\
\text { screen. }\end{array}$ \\
\hline Learning facilities & $\begin{array}{l}\text { - Practicum teaching module } \\
\text { - Power point } \\
\text { - Video } \\
\text { - Practicum tool module } \\
\text { - LCD Projector }\end{array}$ \\
\hline Assessment & $\begin{array}{l}\text { - Written test } \\
\text { - Practice } \\
\text { - Products } \\
\end{array}$ \\
\hline Learning Resources & $\begin{array}{l}\text { - Raspberry Pi Cookbook, Simon Monk. } \\
\text { - Science book for grade VII semester } 12013 \text { curriculum revised edition 2017, } \\
\text { BSE. } \\
\text { - Mathematics book for grade VII semester } 12013 \text { curriculum revised edition } \\
\text { 2017, BSE. }\end{array}$ \\
\hline
\end{tabular}

In learning activities, student will experience using Python language programming in daily life and presents the results of experiments with python and displayed in web or LCD screen. From this learn activities, the student must try to use python programming language and show the result from the experiment.

Teachers needed to use several learning materials such as practicum teaching module to guide the students to do experiment, power point to help the teacher explain the material, video to show the example of experiment application, practicum tool module as the media practice of the student and LCD projector to help when show the power point. The assessment is obtained from the writing test, the practicum process and products created by the students. The third learning material is about Internet of
Things on measurement and Unit. The goal is that students can count and read the value of measurements and units by applying IoT. So that, the basic competency formulated is applying the concept of measuring the quantities using standard units and presenting measurement data using sensors.

This section is focusing on the utilization of measurements and units by IoT. So that the indicators of competence achievement formulated as follows: students are able to measure the measurement and unit, measure the condition of an object using a sensor which represents, count using timers in python programming, make programming to save and display data results in web form, design programming for the application of measurements and units, solve problems by using arithmetic, algebra and integer calculations. The indicators are 
representing C5, C3, C6 and C4 which analyze, evaluate and create items related to means that students are able to apply, IoT on measurement and unit

Table 3

Internet of Things On Measurement And Unit

\begin{tabular}{l|l}
\hline Basic competencies & Apply the concept of measuring the quantities using standard units and sensors. \\
\hline Learning materials & Internet of Things on measurement and Unit \\
\hline Indicator & - Measure the measurement and Unit. \\
& - Measure the condition of an object using a sensor. \\
& - Count using timers in python programming \\
& - Make programming to save and display data results in web form \\
& - Design programming for the application of measurements and units \\
- Solve problems by using arithmetic, algebra and integer calculations.
\end{tabular}

Students will conduct experiments in learning activities to measure the length, mass, time and others and presenting experimental results about measurements with sensors and displayed in web or LCD screen. These activities will encourage students to use python programming language to determine and show the result from the experiment.

Learning facilities needed are practicum teaching module to guide the students to do experiment, power point to help the teacher explain the material, game to make the class fun, video to show the example of experiment application, practicum tool module as the media practice of the student and LCD projector to help when show the power point. The assessment is obtained from the writing test, the practicum process and products created by the students. The fourth learning material is about Internet of Things on acids and bases.

The purpose is that the students can classify the difference between acids and bases and determine the application. In the end of this section, students are expected to master a basic competency: present the results of experiments in investigating the characteristic of acid and base solutions. 
The indicators of competence achievement are: students are able to analyze the differences between acids and bases, compare acids and bases using $\mathrm{PH}$ sensor, demonstrate saving and displaying data results in web, design programming to apply the use of acids and bases classification and solve problems by using arithmetic, algebra and integer calculations. The indicators represents C4, C5, C3 and C6 respectively which means that in the end of this section, students can apply, analyze, evaluate and create related to IoT on the application of acids and bases. The reason of this indicator is this section focused on the classification the difference between acids and bases by IoT.

\section{Table 4}

Internet of Things on the Application of Acids and Bases

\begin{tabular}{|c|c|}
\hline Basic competencies & $\begin{array}{l}\text { Present the results of experiments in investigating the characteristic of acid and } \\
\text { base solutions. }\end{array}$ \\
\hline Learning materials & Internet of Things on the application of acids and bases \\
\hline Indicator & $\begin{array}{l}\text { - Analyze the differences between acids and bases } \\
\text { - Compare acids and bases using PH sensor. } \\
\text { - Demonstrate saving and displaying data results in web. } \\
\text { - Design programming to apply the use of acids and bases classification } \\
\text { - Solve problems by using arithmetic, algebra and integer calculations. }\end{array}$ \\
\hline Learning Activities & $\begin{array}{l}\text { - Investigate the acid and bases by PH sensor. } \\
\text { - Conclude the experimental results about investigations with sensors and } \\
\text { displayed in web or LCD screens. }\end{array}$ \\
\hline Learning facilities & $\begin{array}{l}\text { - Practicum teaching module } \\
\text { - Power point } \\
\text { - Video } \\
\text { - Practicum tool module } \\
\text { - LCD Projector }\end{array}$ \\
\hline Assessment & $\begin{array}{l}\text { - Written test } \\
\text { - Practice } \\
\text { - Products }\end{array}$ \\
\hline Learning Resources & $\begin{array}{l}\text { - Raspberry Pi Cookbook, Simon Monk. } \\
\text { - Science book for grade VII semester } 12013 \text { curriculum revised edition 2017, } \\
\text { BSE. } \\
\text { - Mathematics book for grade VII semester } 12013 \text { curriculum revised edition } \\
\text { 2017, BSE. }\end{array}$ \\
\hline
\end{tabular}

In learning activities, student will investigate acid and bases by $\mathrm{PH}$ sensor and will present experimental results about investigations with sensors and displayed in web or LCD screens. This learning activities will encourage students to use Python programming language to determine and show the result from the experiment.

Teachers need to prepare learning facilities such as practicum teaching module to guide the students to do experiment, power point to help the teacher explain the material, video to show the example of experiment application, practicum tool module as the media practice of the student and LCD projector to help when show the power point. The assessment is obtained from the writing test, the practicum process and products created by the students. 


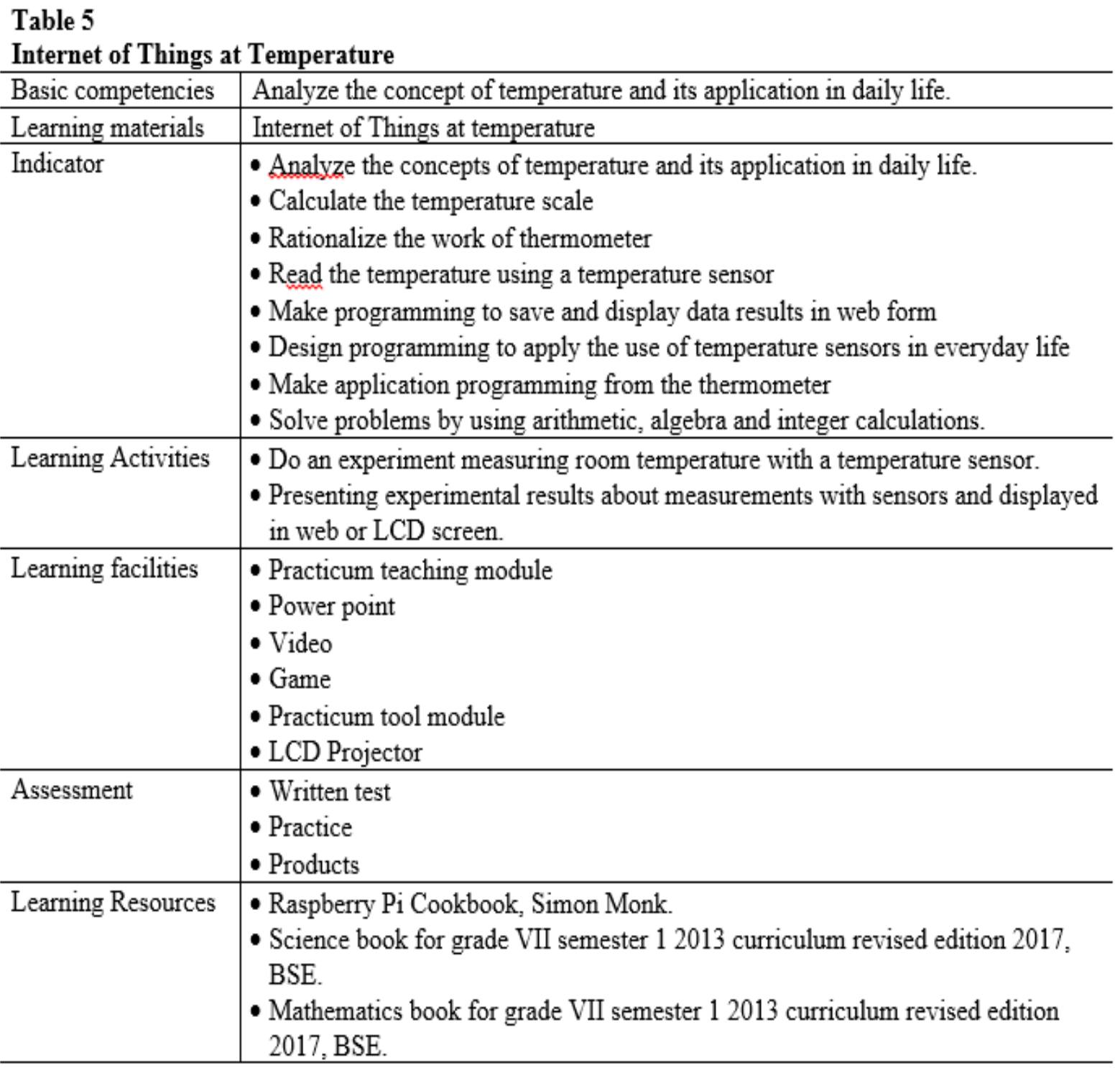

The fifth learning material is about Internet of Things at temperature. The basiccompetency formulated is analyze the concept of temperature and its application in daily life and do experiments to investigate temperature use in everyday life.

The indicators of competence achievement are: students are able to analyze the concepts of temperature and its application in daily life, calculate the temperature scale, rationalize the work of thermometer, read the temperature using a temperature sensor, make programming to save and display data results in web form, design programming to apply the use of temperature sensors in everyday life, make application programming from the thermometer, and solve problems by using arithmetic, algebra and integer calculations. The indicators are representing C4, C2, C1, and C6 respectively. After accomplishing this sections, students can remember, understand, analyze and create items related to IoT at temperature. The reason of the indicators is this section focused on the application of temperature in daily life by IoT.

Student will measure room temperature with a temperature sensor and presenting experimental results about measurements 
with sensors and displayed in web or LCD screen. This learning activity will encourage students to use Python programming language to determine and show the result from the experiment.

Teachers need to prepare practicum teaching module to guide the students to do experiment, power point to help the teacher explain the material, game to make the class fun, video to show the example of experiment application, practicum tool module as the media practice of the student and LCD projector to help when show the power point. The assessment is obtained from the writing test, the practicum process and products created by the students.

Table 6

Internet of Things on Work

\begin{tabular}{l|l}
\hline Basic competencies & Present the experiments results of work. \\
\hline Learning materials & Internet of Things on work \\
\hline Indicator & - Analyze the workings of the force of work \\
& - Measure the speed of an object using a speed sensor. \\
& - Measure object length using a distance sensor. \\
& - Measure the weight of an object using a heavy sensor. \\
& - Count using Timer on python programming \\
& - Demonstrate saving and displaying data results in web. \\
& - Design programming to apply the utilization of work in daily life \\
& - Solve problems by using arithmetic, algebra and integer calculations.
\end{tabular}

The sixth learning material is about Internet of Things on work. The students are expected can comprehend the working of work and force in daily life by IoT. The basic competency is analyze work concepts in daily life and presenting the experiments results of work.

The indicators of competence achievement are: students are able to analyze the workings of the force of work, measure the speed of an object using a speed sensor, measure object length using a distance sensor, measure the weight of an object using a heavy sensor, count using Timer on python programming, demonstrate saving and displaying data results in web, design programming to apply the utilization of work in daily life, and solve problems by using arithmetic, algebra and integer calculations. The indicators are representing C4, C5, C3, and C6. In the end of this section, students can apply, analyze, evaluate and create items related to Iot on work. This section focuses on the utilization of work in daily life by IoT.

Beyond Words Vol.6 No.2 (2018) 
Students will measure work by sensors and presenting experimental results about measurements with sensors and displayed in web or LCD screen. This learning activity will encourage students to use Python programming language to determine and show the result from the experiment.

Teachers need to prepare practicum teaching module to guide the students to do experiment, power point to help the teacher explain the material, video to show the example of experiment application, practicum tool module as the media practice of the student and LCD projector to help when show the power point. The assessment is obtained from the writing test, the practicum process and products created by the students.

\section{Conclusion}

The process of designing a syllabus for computer extracurricular at the junior high school level based on IoT has been successfully made in accordance with Indonesian government regulations and refer to Revised Bloom Taxonomy.

There are six competency standards related to IoT and develop into six basic competencies for syllabus design. Six basic competencies are adapted to IoT-based learning materials, then elaborated in indicators of competency achievement from Revised Bloom Taxonomy. The results show that all indicators mentioned in the syllabus are in accordance with the competency standards of junior high school students. In terms of the Knowledge dimension, the factual, conceptual, procedural and metacognitive points of knowledge have been fulfilled with the emergence of cognitive domain verb in each indicator of achievement of competence in the syllabus that has been designed.
Learning activities in the syllabus are comprehensively made so that students can perform practical work in accordance with the learning materials.

Learning facilities in each section cover practicum teaching modules, power points, videos, practicum tool modules, and LCD projectors. The preparation of modules, power points and videos will be compiled in different research later on. The making of learning facilities will later refer to the syllabus designed in this study.

The assessment for students in the first section is limited to written tests, while in the second to sixth section include written tests, practicum and making products. Each assessment is adjusted to the basic competency and learning materials that have been formulated.

To find out the effectiveness of the syllabus that has been designed in this study, researchers need to do further research by examining the syllabus implementation in the destination school first.

\section{(C) Dias Agata, Adnan Rachmad Anom Besari, Iwan Kurnianto Wibowo, and Berliana Cahyaniati Purnomo Putri}

Dias Agata, S.S., M.Pd. is a Lecturer at Politeknik Elektronika Negeri Surabaya, where she teaches English, Communication Skills and Entrepreneurships. She is experienced in the preparation of curriculum and preparation of semester learning plans (RPS) of English in the Computer Engineering Study Program at PENS. Dias is also proficient in public speaking and an entrepreneurial enthusiast. Please email diasagata@pens.ac.id to contact Dias. 
Adnan Rachmad Anom Besari, S.ST., M.Sc. is a Lecturer at Computer Engineering Study Program, Politeknik Elektronika Negeri Surabaya, where he teaches Operating Systems, Syntax and Programming Language, Computer Vision and others. He is experienced in software development. Anom recently serves as head of the student activity center and provides access for students to excel in the non-academic field. Please email anom@pens.ac.id to contact Anom.

Iwan Kurnianto Wibowo, S.ST., M.T. is a Lecturer at Computer Engineering Study Program, Politeknik Elektronika Negeri Surabaya, where he teaches Basic Programming, Robotics, Embedded System and Electronic Network. He is experienced in designing soccer robots and autopilot system for navigation of unmanned ships. Iwan has successfully supervised many students to win robot contests at national and international levels. Please email eone@pens.ac.id to contact Iwan.

Berliana Cahyaniati Purnomo Putri, is a final year student at Computer Engineering Study Program, Politeknik Elektronika Negeri Surabaya. Berliana is currently working on her final project about syllabus design for Internet of Things based computer extracurricular. Please email berlianacpp@gmail.com to contact Berliana.

\section{References}

Anggraini, Flatya Indah \& Huzaifah, Siti. (2017). Implementasi STEM dalam pembelajaran IPA di Sekolah Menengah Pertama. Mahapeserta didik Program Studi Pendidikan Biologi, Fakultas Keguruan dan Ilmu Pendidikan, Universitas Sriwijaya.

Barrie, Sarah Barradellm Simon \& Peseta, Tai. (2017). Ways of thinking and practising: Highlighting the complexities of higher education curriculum. Chalmers University of Technology.

Depdiknas. (2005). Peraturan Pemerintah

RI Nomor 19 tahun 2005 tentang Standar Nasional Pendidikan (Pasal 28). Jakarta.

Siegfried, R. M., Siegfried, J. P., \& Alexandro, Gina. (2016). A Longitudinal Analysis of the Reid List of First Programming Languages. Adelphi University.

Adam, Aulia. (2017). Selamat Tinggal Generasi Milenial, Selamat Datang Generasi Z, https://tirto.id/selamattinggal-generasi-milenial-selamatdatang-generasi-z-cnzX.
Annisa, Finastri. (2017). Mengenal Indonesia Lewat Data: Generasi Millenial dan Terbukanya Peluang Ekonomi Baru Indonesia. http://ideannisa.com/2017/ 05/04/peluang-ekonomi-bonusdemografi-millenial/.

Alfama, Adelian. (2017). Increasing Persistence of Collage Students in Science Technology Engineering and Mathematic (STEM). Sekolah Tinggi Teknologi Dumai.

Sanner, M. F. (1999). Python: A Programming Language for Software Integration and Development. North Torrey Pines Road, La Jolla.

Kemendikbud. (2003). Undang-Undang Republik Indonesia Nomor 20 Tahun 2003 Tentang Sistem Pendidikan Nasional.

Hardyanto, R. Hafid. (2017). Konsep Internet of Things pada Pembelajaran Berbasis Web. Universitas PGRI Yogyakarta.

Rao, A. R., Clarke, Daniel. (2018). Development of an Embedded System 
Course to Teach the Internet-of-Things. Fairleigh Dickinson University.

Kemendikbud. (2016). Peraturan Menteri

Pendidikan dan Kebudayaan Nomor 20 Tahun 2016 tentang Standar Kompetensi Lulusan Pendidikan Dasar dan Menengah.
Rukmini, E. (2009). Deskripsi Singkat Revisi Taksonomi Bloom. Majalah Ilmiah Pembelajaran. journal.uny.ac.id

Weber, Rolf H., Weber, Romana. (2010). Internet of Things. Springer-Verlag Berlin Heidelberg. 